\title{
MEMBANGUN LINGKUNGAN SEHAT DI KAWASAN WISATA PANTAI SAWARNA
}

\author{
Leila Mona Ganiem', Rosmawaty Hilderiah Pandjaitan² \\ ${ }^{1}$ Magister Ilmu Komunikasi Universitas Mercu Buana Jakarta \\ leila.mona@merbubuana.ac.id \\ ${ }^{2}$ Magister Ilmu Komunikasi Universitas Mercu Buana Jakarta \\ bundarossa@mercubuana.ac.id
}

\begin{abstract}
ABSTRAK
Pantai Sawarna, desa wisata yang memiliki potensi alam yang sangat indah dan banyak dikunjungi wisatawan kini berubah menjadi kotor karena banyak sampah serta sedikit sarana prasarana yang mendukung lingkungan sehat. Kondisi tersebut berpotensi menimbulkan penularan penyakit. Perlunya upaya kolektif untuk menjaga lingkungan yang sehat, salah satunya adalah perlunya partisipasi masyarakat untuk ikut menciptakan lingkungan yang sehat melalui pendekatan Personal Social Responsibility atau PSR. Konsep PSR dilandasi oleh sikap altruisme. Sikap ini merefleksikan tindakan sukarela untuk membantu orang lain tanpa pamrih atau keinginan untuk beramal baik. PSR dapat membangun karakter pada pelakunya. Karakter tersebut adalah toleransi, bersahabat/komunikasif, peduli lingkungan, peduli sosial, tanggung jawab, kreatif. Tujuan pengabdian pada masyarakat ini adalah memberikan pelatihan komunikasi lingkungan sehat dalam membangun sikap peduli terhadap lingkungan di kawasan Pantai Sawarna. Khalayak sasaran adalah tokoh masyarakat (tokoh agama, pendidik, pelaku usaha kecil dan anggota masyarakat di sekitar pantai sejumlah 20 orang. Metode penyampaian adalah dengan presentasi dengan contoh, dialog, dan focus group discussion. Peserta pengabdian masyarakat ini menjadi lebih menyadari pentingnya menjaga lingkungan sehat di wilayah mereka serta dampaknya pada kehidupan mereka ketika melakukannya. Peserta menjadi berminat melakuan upaya aktif dalam menjaga lingkungan sehat. Perserta juga berharap kontribusi kolektif dari pejabat setempat, unsur masyarakat lainnya serta para wisatawan dalam menjaga lingkungan yang sehat.
\end{abstract}

Kata kunci: Lingkungan sehat; Pantai Sawarna; Personal Social Responsibility.

\section{PENDAHULUAN}

Salah satu desa wisata dengan panorama yang indah di kecamatan Bayah, kabupaten Lebak, adalah "Sawarna". Desa ini banyak dikunjungi oleh wisatawan domestik maupun mancanegara. Potensi wisata alam yang menjadi daya tarik wisata di Desa Sawarna ini terdiri dari dua kategori, yaitu obyek wisata pantai dan goa-goa. World Bank menyatakan bahwa pariwisata merupakan penyumbang yang paling mudah untuk devisa dan Pendapatan Domestik Bruto (PDB) suatu negara. Laporan Akuntabilitas Kementerian Pariwisata (LAKIP) Tahun 2018 menyebutkan bahwa kontribusi sektor pariwisata terhadap PDB nasional tahun sejumlah 5,25\% dan jumlah penerimaan devisa dari sektor pariwisata sejumlah 223 triliun rupiah. Sektor pariwisata merupakan penyumbang devisa kedua di Indonesia.

Kekayaan alam di sektor pariwisata yang adalah aset potensial untuk meningkatkan pertumbuhan ekonomi. Peluang untuk memperoleh pendapatan, peningkatan standar hidup masyarakat, menstimulasi sektor-sektor produksi, menciptakan lapangan kerja bagi masyarakat setempat, menggerakkan usaha kecil menengah seperti kuliner, cenderamata, transportasi dan lainnya; dan menarik investor dari dalam atau luar negeri untuk turut membangun kawasan pariwisata di kawasan tersebut (Kaulina, Fredinan, \& Vincentius, 2017).

Untuk dapat menarik wisatawan, kekayaan alam perlu dilakukan pengembangan. Dari berbagai penelitian disimpulkan bahwa khususnya pantai, sangat penting adanya pengelolaan lingkungan secara baik, karena pariwisata menuntut kebersihan lingkungan yang sangat tinggi (Nawawi, Ahmad, 2013, Obonyo, George Otieno \& Erick Victor Onyango Fwaya, 2012). 
Realitasnya, Pantai Sawarna kurang mendapat perawatan karena banyak tumpukan sampah dipesisir pantai dan sarana pendukung yang kurang memadai. Penelitian Stephanie (2015) menyimpulkan bahwa masalah yang sering dikeluhkan pengunjung di Pantai Sawarna adalah terkait fasilitas fisik, sarana prasarana yang masih minim seperti lampu penerangan jalan, bangkubangku atau shelter yang sudah tidak kokoh lagi dan jumlahnya sedikit, fasilitas pengaman pantai, tempat makan serta toilet umum.

Selain masalah kenyamanan, berbagai masalah kesehatan dapat timbul karena kurang sehatnya lingkungan wisata. Wisatawan juga rentan sakit karena mereka belum memiliki kekebalan terhadap penyakit. Survei yang dilakukan di Amerika menyebutkan wisatawan internasional sering terkena Malaria (84\%), diare (71\%) dan demam tifoid (53\%) (Streit et al. 2012). Akibat udara tidak sehat, penularan melalui udara dapat menimbulkan penyakit Inpeksi saluran nafas, tuberculosis, batuk dll. Sejumlah riset (Steffen et al. 2004; Hill, 2000; VonSonnenburg etal. 2000), menyimpulkan bahwa terdapat $20-60 \%$ wisatawan yang mengunjungi negara berkembang mengalami diare akut karena pengolahan makanan yang kurang higienis. Situasi ini diperburuk dengan belum diwajibkannya wisatawan asing yang berkunjung ke Indonesia untuk memiliki asuransi kesehatan, sehingga potensi penanganan ketika sakit juga minim.

Masalah lain yang menjadi kendala penting terciptanya lingkungan sehat adalah minimnya partisipasi masyarakat dalam pemberdayaan lingkungan sehat di daerah Pantai Sawarna.

Pentingnya partisipasi masyarakat adalah karena masyarakat merupakan pemeran dan stakeholder utama dalam mengelola, memberdayakan dan memanfaatkan wisata di suatu daerah. Pelibatan masyarakat dalam menciptakan kebersihan, kesehatan dan kebersamaan di wilayahnya perlu dilakukan dengan program pemberdayaan. Membangun komunitas dalam konteks pemberdayaan merupakan proses transisi dari keadaan ketidakberdayaan ke keadaan kontrol relatif atas kehidupan seseorang, takdir, dan lingkungan (Sadan,1997). Inovasi lingkungan dapat memberi nilai tambah melalui kesadaran masyarakat sendiri untuk mengambil sikap yang membuat kontrol terhadap kondisi lingkungan (Binkhorst dan Dekker, 2009).

Beberapa bukti positif adanya partisipasi masyarakat, misalnya, di kabupaten Badung, Bali, keikutsertaan dalam mengelola sampah ternyata berpengaruh signifikan terhadap pendapatan masyarakat (Yuliastuti, Mahendra dan Made (2013). Penelitian lain oleh Sulistiyorini, Darwis, Gutama (2015) menyimpulkan bahwa masyarakat di Margaluyu, kelurahan Cicurug, Jawa Barat mau berpartisipasi dalam pengelolaan sampah. Mereka terlibat sejak dalam tahap perencanaan, pembuatan keputusan, hingga pengelolaan langsung di lapangan seperti pemilahan sampah, hingga membuat produk daur ulang dari sampah.

Atas berbagai kondisi di Pantai Sawarna, maka dirasa perlu pelatihan komunikasi. Konsep yang mendukung dari kegiatan pelatihan komunikasi lingkungan sehat adalah konsep altruism. Sikap altruisme merefleksikan tindakan sukarela untuk membantu orang lain tanpa pamrih atau keinginan untuk beramal baik (Scroder, Penner, Dovido \& Piliavin, 1995), memberi perhatian pada orang lain, membantu orang lain dan meletakkan kepentingan orang lain diatas kepentingan sendiri (Myers, 1987:383).

Sebagai solusi dari masalah social, altruism dihubungkan dengan Personal Social Responsibility$P S R$, atau kesadaran diri untuk bertanggung jawab terhadap kebaikan masyarakat (Ganiem, Ambadar, Soekardjo, 2015). PSR juga menguntungkan bagi pelakunya, yaitu terbangunnya karakter toleransi, bersahabat/komunikasif, peduli lingkungan, peduli sosial, tanggung jawab, 
kreatif (Ganiem, 2018). Pembahasan PSR akan diarahkan pada upaya untuk membentuk lingkungan yang sehat di pantai Sawarna.

Upaya PSR atau melakukan pengabdian masyarakat, dapat didukung dengan konsep yang dikembangkan oleh Everett Rogers (1964), yaitu difusi inovasi. Agar gagasan - berupa dukungan untuk membangun lingkungan sehat- dapat diterima, maka perlu dikembangkan secara perlahan melalui sebuah proses konstruksi social. Ketika penerima pesan melihat manfaat, kesesuaian, mampu dicoba, memiliki kerumitan rendah, maka suatu gagasan atau inovasi akan lebih cepat diadopsi.

Inovasi lingkungan sehat di Pantai Sawarna, diharapkan membuat nilai tambah pada sisi ekonomi. Hal ini sejalan dengan kesimpulan penelitian Binkhorst dan Dekker (2009) yang menyatakan bahwa masyarakat yang kreatif atas kesadaran sendiri, melakukan inovasi dengan mengontrol kondisi lingkungan. Sebagai upaya menghidupkan inovasi pariwisata, agar masyarakat memiliki tanggung jawab sosial individu (PSR) dengan kontrol kondisi lingkungan yang sehat, maka penulis melakukan kegiatan pengabdian pada masyarakat di Pantai Sawarna dengan tema: "Pelatihan Komunikasi Lingkungan Sehat dalam Membangun Sikap Peduli Terhadap Lingkungan di Kawasan Pantai Sawarna”.

Tujuan dari kegiatan pengabdian masyarakat tersebut ada dua. Pertama, untuk meningkatnya pengetahuan atau edukasi tentang pentingnya lingkungan sehat, termasuk diantaranya masalah sampah plastik; kedua, memotivasi pentingnya partisipasi masyarakat yang dapat diekspresikan dalam pembuatan rencana program tanggung jawab sosial individu (PSR) untuk ikut terlibat dalam menciptakan lingkungan sehat di Pantai Sawarna.

\section{METODE PELAKSANAAN PKM}

Khalayak yang direncanakan menjadi sasaran dari kegiatan pengabdian masyarakat ini adalah perempuan pelaku usaha, ibu rumah tangga di sekitar pantai Sawarna. Namun, pada pelaksanaannya, karena para ibu-ibu sedang menghadiri acara lain yang mendadak, maka peserta yang hadir adalah para pria. Mereka adalah tokoh masyarakat, pelaku usaha, anggota masyarakat sekitar pantai Sawarna. Perubahan ini tidak terlalu berdampak signifikan, karena peserta masih dalam peran dan aktifitas yang sama.

Acara pengabdian masyarakat dilaksanakan pada tanggal 11 Februari 2019, jam: 08.00-10.00 WIB, bertempat di Andrew Homestay Sawarna, Jl. Sawarna KM. 1, Cibeas, Sawarna, Bayah, Sawarna, Bayah, Kabupaten Lebak, Banten 42393, dengan jumlah peserta 20 orang.

Dalam kegiatan tersebut, penulis melakukan sejumlah hal sebagai berikut:

1. Pre-test secara kualitatif untuk menggali pemahaman peserta tentang lingkungan sehat

2. Penyampaian materi: pentingnya lingkungan sehat, dampak lingkungan sehat dan tidak sehat pada kehidupan masalah yang terjadi pada lingkungan pantai.

3. Motivasi dengan pendekatan konsep Personal Social Responsibility atau PSR termasuk inspirasi kegiatan yang dapat menimbulkan sikap peduli pada lingkungan sehat.

4. Focus group discussion (FGD) untuk menggali rencana tindakan dari peserta.

5. Diskusi dan Tanya jawab

6. Post test 
Materi disampaikan oleh tim penulis dengan pertimbangan bahwa tim memiliki pengetahuan dan pengalaman dalam menyampaikan pesan terkait lingkungan sehat, memahami konsep PSR dan mampu mengelola focus group discussion.

\section{HASIL DAN PEMBAHASAN}

Fokus utama kegiatan ini adalah membangun pemahaman dan kesadaran anggota masyarakat akan pentingnya lingkungan hidup sehat dan berbagai beragam upaya yang dapat dilakukan. Kegiatan tersebut merupakan bentuk pengkomunikasian pentingnya lingkungan sehat dan selanjutnya membangun sikap peduli masyarakat terhadap lingkungan di Pantai Sawarna.

Tabel 1 Jumlah Peserta Berdasarkan Pekerjaan di Desa Sawarna

\begin{tabular}{|c|c|c|c|}
\hline $\mathrm{No}$ & Pekerjaan & Jumlah & Persentase \\
\hline 1 & Guru & 2 & 10 \\
\hline 2 & Ustad & 1 & 5 \\
\hline 3 & Pedagang/Pelaku Usaha Kecil & 5 & 25 \\
\hline \multirow[t]{2}{*}{4} & Buruh & 12 & 60 \\
\hline & & 20 & 100 \\
\hline
\end{tabular}

Tabel 2. Jumlah Peserta Berdasarkan Pekerjaan di Desa Sawarna

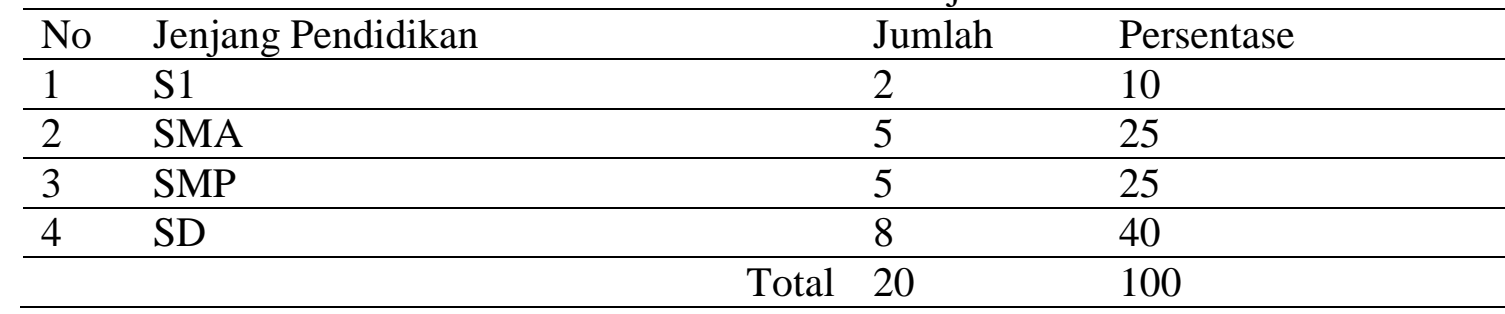

Tema yang disampaikan dalam Pengabdian pada Masyarakat yaitu "Pelatihan Komunikasi Lingkungan Dalam Membangun Sikap Peduli Terhadap Lingkungan di Kawasan Pantai Sawarna" Pemateri diisi oleh Dr. Leila Mona Ganiem dan Dr. Rosmawaty HP.

Sebelum pemaparan materi, dilakukan pre-test dengan menanyakan pada peserta mengenai pemahaman mereka terkait lingkungan sehat. Jawaban beragam disampaikan oleh peserta, namun kebanyakan peserta memahami pentingnya lingkungan sehat bagi kehidupan dan dampaknya bagi kesehatan secara umum. Terkait kepedulian sosial, jawaban peserta cenderung melakukan kepedulian di lingkungan terdekat rumahnya, daripada ikut terlibat dalam menciptakan lingkungan sehat di pantai Sawarna.

Pada kesempatan tersebut juga diulas kisah-kisah inspiratif PSR melalui tampilan video- video yang menggugah hati serta dampat ber - PSR, kepedulian kita mengubah masyarakat menjadi lebih baik serta ikut mengatasi masalah sosial. Hasil dari Focus Group Discussion disimpulkan sebagai berikut: 
Tabel 3. Kesimpulan Focus Group Discussion

\begin{tabular}{|c|c|c|}
\hline No & Bahan Diskusi & Jawaban Peserta Diskusi \\
\hline 1 & $\begin{array}{l}\text { Sebagai anggota } \\
\text { masyarakat, } \\
\text { mengapa penting } \\
\text { mereka memiliki } \\
\text { lingkungan sehat }\end{array}$ & $\begin{array}{l}\text { - Karena lingkungan sehat membuat nyaman } \\
\text { - Karena daerah wisata memungkinkan adanya penyebaran penyakit dari } \\
\text { pendatang } \\
\text { - Karena lingkungan sehat membuat pendatang lebih tertarik datang dan akan } \\
\text { menguntungkan warga setempat untuk menjalankan bisnis } \\
\text { - Karena lingkungan adalah tempat hidup mereka dan tanggung jawab mereka } \\
\text { untuk menjaganya } \\
\text { - Karena ingin lingkungan tidak kotor atau rusak }\end{array}$ \\
\hline 2 & $\begin{array}{l}\text { Hal-hal yang dapat } \\
\text { mereka lakukan } \\
\text { untuk membantu } \\
\text { agar lingkungan di } \\
\text { Pantai Sawarna } \\
\text { menjadi lingkungan } \\
\text { yang sehat }\end{array}$ & $\begin{array}{l}\text { - } \quad \text { Buang sampah pada tempat sampah } \\
\text { - } \quad \text { Kerja bakti warga di lingkungan } \\
\text { - Meminimalisir penggunaan kantong plastik } \\
\text { - Membuat tempat sampah sederhana } \\
\text { - Membuat penerangan sederhana dari hasil pengumpulan dana masyarakat } \\
\text { - Memperkenankan wisatawan menggunakan sarana toilet pribadi terdekat }\end{array}$ \\
\hline 3 & $\begin{array}{l}\text { Harapan mereka } \\
\text { terkait upaya } \\
\text { menjaga } \\
\text { lingkungan yang } \\
\text { sehat }\end{array}$ & $\begin{array}{l}\text { - Aparat desa (kelurahan, kecamatan) lebih aktif menjaga memberdayakan } \\
\text { lingkungan } \\
\text { - Aparat desa menyediakan fasilitas fisik, sarana-prasarana seperti penerangan } \\
\text { jalan, tempat duduk, toilet } \\
\text { - Wisatawan peduli menjaga kebersihan dengan tidak membuang sampah } \\
\text { sembarangan, termasuk sampah plastik } \\
\text { - Wisatawan mau memunguti sampah di sekitar pantai Sawarna. } \\
\text { - Perusahaan atau ormas, LSM dan organisasi lainnya ikut membantu menjaga } \\
\text { kesehatan lingkungan. }\end{array}$ \\
\hline
\end{tabular}

Posttest dilakukan dalam bentuk kuisioner. Hasilnya sebagai berikut:

(a)Pertanyaan pertama terkait pendapat peserta tentang kemampuan pemateri dalam menyampaikan pelatihan apakah pemateri mampu menyampaikan isi pelatihan. Sejumlah $55 \%$ peserta (11 orang) merasa sangat puas; $40 \%$ peserta ( 8 orang) merasa puas; dan $5 \%$ peserta, yaitu (1 orang) merasa cukup.

(b) Pertanyaan kedua, mengenai kegiatan PPM ini dapat membantu memberikan kesadaran untuk membangun sikap peduli terhadap lingkungan di kawasan pantai Sawarna. Sejumlah $75 \%$ peserta (15 orang) menyatakan pelatihan tersebut menyatakan sangat membantu; sejumlah $25 \%$ (5 orang) menyatakan kegiatan ini membantu.

(c) Pertanyaan ketiga, mengenai kesesuaian pelatihan komunikasi lingkungan yang diselenggarakan ini dengan kebutuhan masyarakat di kawasan Pantai Sawarna. Sejumlah 40\% peserta (8 orang) menyatakan sangat sesuai; $50 \%$ peserta (10 orang) menyatakan sesuai; sejumlah $10 \%$ peserta ( 2 orang) menyatakan cukup sesuai

(d) Pertanyaan keempat, mengenai tempat penyelenggaraan pelatihan ini apakah cukup sesuai bagi para peserta. Sejumlah $40 \%$ peserta ( 8 orang) menyatakan sangat sesuai; $50 \%$ peserta (10 orang) menyatakan sesuai; sejumlah $10 \%$ peserta ( 2 orang) menyatakan cukup sesuai.

(e) Pertanyaan kelima, mengenai kesesuaian fasilitas pelatihan komunikasi lingkungan dalam membangun sikap peduli terhadap lingkungan di kawasan Pantai Sawarna. Sejumlah 50\% peserta (10 orang) menyatakan sangat baik; $30 \%$ peserta (6 orang) menyatakan baik; sejumlah $20 \%$ peserta ( 2 orang) menyatakan cukup baik 
(f) Pertanyaan keenam, mengenai manfaat kegiatan pelatihan komunikasi lingkungan dalam membangun sikap peduli terhadap lingkungan di kawasan Pantai Sawarna. Sejumlah $60 \%$ peserta (12 orang) menyatakan sangat bermanfaat; $40 \%$ peserta ( 8 orang) menyatakan bermanfaat.

Dapat disimpulkan bahwa kegiatan ini dirasakan berhasil bagi masyarakat setempat dengan indikator (a)Para peserta merasa puas dan sangat puas terhadap kegiatan pengabdian masyarakat tersebut, (b)Para peserta berminat untuk mengekspresikan sikap kepedulian pada lingkungan sehat di kawasan Pantai Sawar, dan (c) Para peserta memiliki gagasan untuk melakukan dan melanjutkan kegiatan yang baik terkait kepedulian terhadap lingkungan sehat di Pantai Sawarna

\section{Pembahasan}

Terkait pemaparan materi mengenai pentingnya menjaga lingkungan yang sehat di kawasan wisata pantai, diharapkan dapat meningkatkan pemahaman tentang lingkungan sehat yang berdampak pada kondisi fisik - ekonomi masyarakat. Upaya ini juga sebagai dukungan atas adanya sektor pariwisata yang merupakan penyumbang devisa nomor dua di Indonesia. Penelitian World Bank menyimpulkan bahwa pariwisata merupakan penyumbang yang paling mudah untuk devisa dan pendapatan domestik bruto (PDB) suatu negara.

Penelitian dari (Kaulina, Fredinan, \& Vincentius, 2017) mengkonfirmasi bahwa kekayaan sumber daya alam merupakan aset potensial pengembangan kepariwisataan yang mampu meningkatkan pertumbuhan ekonomi melalui pendapatan dan standart hidup masyarakat serta menstimulasi sektor-sektor produksi, menciptakan lapangan kerja bagi masyarakat setempat dan menarik investor dari dalam atau luar negeri untuk turut membangun kawasan pariwisata di kawasan tersebut.

Untuk itu spesifik terkait pantai, maka pengelolaan lingkungan secara baik adalah keharusan, karena pawisisata menuntut kebersihan lingkungan yang sangat tinggi dan peningkatan pendapatan masyarakat di sekitarnya (Nawawi, 2013; Obonyo, Otieno \& Fwaya, 2012). Secara factual, hasil penelitian Sthepanie (2015) mengkonfirmasi sejumlah masalah yang sering dikeluhkan oleh pengunjung di Pantai Sawarna adalah terkait fasilitas fisik, sarana prasarana yang masih minim seperti lampu penerangan jalan, bangku-bangku atau shelter yang sudah tidak kokoh lagi dan jumlahnya sedikit, fasilitas pengaman pantai, tempat makan serta toilet umum.

Terkait pemahaman akan memungkinkannya muncul penyakit akibat lingkungan yang tidak sehat, sebagian peserta mampu melihat dampak dari lalu lintas wisatawan terhadap kehidupan mereka, meski demikian, mereka belum memahami dampak dari lingkungan yang tidak sehat terhadap kesehatan wisatawan yang cenderung rentan atas penyakit karena mereka belum memiliki kekebalan terhadap penyakit yang baru mereka dapatkan.

Pada hasil post test disimpulkan bahwa para peserta cenderung memahami pentingnya kesadaran akan peran masyarakat yang peduli terhadap lingkungan sehat serta bersedia menciptakannya, bahkan sebagian dari mereka telah berkontribusi terhadap kesehatan lingkungan. Hal ini sejalan dengan hasil penelitian dari Buana dan Sunarta (2015) mengenai kebersihan lingkungan di Pantai Sanur. Yang menarik dari penelitian Buana dan Sunarta adalah bahwa di pesisir Pantai Sanur ada sector informal yang bersedia ikut menjaga kebersihan Pantai Sanur. Kondisi ini dapat dilakukan karena adanya dukungan sektor formal seperti para pejabat wilayah atau pengelola pantai untuk menetapkan kewajiban setiap pedagang yang berlokasi di Pantai Sanur untuk menjaga kebersihan dan melakukan kegiatan yang berkaitan dengan kebersihan. Hasil penelitian mereka juga mengkonfirmasi bahwa para pedagang di pantai Sanur dan partisipasi masyarakat memiliki peran 
dalam mewujudkan kebersihan, seperti menyapu, mengumpulkan sampah dan melindungi lingkungan

Kesediaan masyarakat pendukung seperti LSM, Perusahaan, Partai Politik, Ormas yang menyelenggarakan kegiatan bersih-bersih di lingkungan, juga berdampak positif bagi pantai Sawarna, karena selain menimbulkan kebersihan, mendukung kepedulian sesame terhadap lingkungan sehat, juga adanya publikasi media atas kinerja mereka dan hal ini, memberi kesan positif ketika pantai bersih atau kotor.

Terkait konsep Personal Social Responsibility, dapat disimpulkan dari hasil focus group discussion, peserta berminat untuk melakukan sejumlah kegiatan secara iklas, karena didasari oleh kepedulian, yang membawa manfaat. Masing-masing individu dapat menjalankan sesuai kapasitasnya serta kebaikan yang mereka lakukan berdampak menular pada orang lain untuk juga berbuat baik. Misalnya seperti membuang sampah pada tempat sampah, Kerja bakti warga di lingkungan, Meminimalisir penggunaan kantong plastik, Membuat tempat sampah sederhana, Membuat penerangan sederhana dari hasil pengumpulan dana masyarakat, Membuatkan bangkubangku dari sumber daya yang ada di lingkungan seperti kayu, Memperkenankan wisatawan menggunakan sara toilet umum di wilayah terdekat. Semua ini sejalan dengan konsep PSR yang memiliki karakteristik: ikhlas, peduli, bermanfaat, semua orang bisa melakukan dan kebaikan tersebut menular pada orang lain (Ganiem, Ambadar, \& Soekardjo, 2015).

Kemauan masyarakat untuk berpartisipasi dalam menjaga lingkungan yang sehat juga bervariasi. Dalam penelitian dari Sulistiyorini, Darwis \& Gutawa (2015), terhadap partisipasi masyarakat dalam mengelola sampah di lingkungan masyarakat Margahayu, menunjukkan adanya masyarakat yang berkenan berpartisipasi tingkat tinggi, tingkat partisipasi sedang dan tingkat partisipasi rendah.

Untuk meningkatkan partisipasi masyarakat, kegiatan pemberdayaan seperti pelatihan, diskusi, motivasi dan penggerakan langsung diharapkan akan lebih efektif. Dalam konsep difusi inovasi, Everett Rogers (1964) menyatakan bahwa proses sosial yang mengomunikasikan ide baru dapat dikembangkan perlahan-lahan. Tahapan difusi inovasi yaitu dari mulai tahap pengetahuan, persuasi, keputusan, implementasi, dan konfirmasi memang perlu dijalankan. Namun, pada kegiatan pengabdian masyarakat ini, karena keterbatasan waktu, tahapan tidak secara lengkap diimplementasikan. Tahapan yang dilakukan adalah pengetahuan, persuasi dan keputusan untuk akan berperilaku menciptakan lingkungan sehat. Sementara tahap implementasi dan konfirmasi masih belum dijalankan. Reaksi positif dari masyarakat yang dapat dilihat dari hasil focus group discussion dan post test cukup menggembirakan sebagai fondasi dari pemberdayaan kepedulian masyarakat terkait lingkungan sehat.

\section{KESIMPULAN}

Pengabdian masyarakat yang penulis lakukan di Pantai Sawarna disambut antusias oleh para peserta karena kehadiran tersebut mendukung agar lingkungan mereka menjadi lebih sehat melalui kegiatan berbagi wawasan dan motivasi untuk lebih peduli pada lingkungan sehat. Para peserta menyatakan dirinya lebih melihat pentingnya kepedulian dalam menjadikan lingkungan hidup mereka, yaitu Pantai Sawarna menjadi lingkungan sehat. Para peserta merasa perlu adanya kontribusi aktif dari pejabat setempat dan unsur masyarakat lainnya untuk bersama-sama memiliki kepedulian pada lingkungan sehat di kawasan Pantai Sawarna. Peserta meyakini pentingnya kesadaran dari para wisatawan untuk ikut andil dalam menjaga lingkungan sehat di kawasan 
tersebut. Para peserta berharap agar kegiatan pengabdian masyarakat serupa kegiatan ini, dapati dipertahankan dan diperluas jangkauannya, terutama pada para pejabat setempat di lingkungan agar semakin banyak para pelajar yang memiliki kebiasaan

\section{Ucapan Terimakasih}

Terima kasih kami sampaikan kepada Rektor Universitas Mercubuana, Kepala PPM dan berbagai pihak atas dukungannya dalam melaksanakan pengabdian masyarakat. Kegiatan pengabdian masyarakat ini masih belum mencapai target ideal karena keterbatasan waktu dan dana yang tersedia. Untuk mencapai tujuan yang diinginkan, menurut kami perlu kiranya dilakukan kegiatan pengabdian masyarakat di lain waktu sebagai kelanjutan kegiatan tersebut.

\section{REFERENSI}

Binkhorst, E., \& Teun den Dekker. (2009). Agenda for Co-Creation Tourism Experience Reseach. Journal of Hospitality Marketing \& Management, 18(2), 311-327.

Buana, D. W, \& Sunarta, I.N. (2015). Peranan sektor informal dalam menjaga kebersihan lingkungan di daya tarik wisata pantai sanur. Jurnal Destinasi Pariwisata, 3, (1) 35-44.

Ganiem, L.M. (2018). Mengembangkan 'Personal Social Resposibility (PSR)’ Dalam Membangun Karakter Mahasiswa. Jurnal Unsoed Acta Diurna, 14 (2). 34-47

Ganiem, LM., Ambadar., \& Soekardjo. (2015). PSR (Personal Sosial Resposibility) Aku, Kamu, Kita Bisa. Prenada Media Kencana, Jakarta.

Hill, D.R. 2000. Occutence and self treatment of diarrhea in a large cohort of americans traveling to developing countries. Am J Prop Med Hvg, 62, 585-589.

Kaulina, S., Yulianda, F., \& Siregar, V. (2017). Kajian Pengembangan Wisata Pantai dan Wisata Selancar Berbasis Potensi Sumberdaya Alam di Desa Sawarna, Banten. https://repository.ipb.ac.id/handle/123456789/87413.

Laporan Akuntabilitas Kementerian Pariwisata (LAKIP) Tahun 2018. http://www.kemenpar.go.id/post/laporan-akuntabilitas-kementerian-pariwisata-lakiptahun-2018.

Myers, D. (1987). Psikologi sosial. Salemba Humanika, Jakarta.

Nawawi, A. (2013). Partisipasi masyarakat dalam pengelolaan wisata pantai depok di desa kretek parangtritis. Jurnal Nasional Pariwisata, 5, (2) 103-109.

Obonyo, G., \& Fwaya. (2012). Integrating Tourirsm With Rural Development Strategies in Western Kenya. International Journal of Hospitality \& Tourism Systems, 5( 2).

Rogers, E.M. (2003). Diffusion of innovations, 5th Edition. Free Press, New York.

Sadan, E. (1997). Empowerment and Community Planning: Theory and Practice of PeopleFocused Social Solutions. Hakibbutz Hameuchad Publishers. Tel Aviv.

Scroder, Penner, Dovido \& Piliavin, (1995). The psychology of helping and altruism: Problems and puzzles. McGraw-Hill, New York.

Streit., Marano., Beekman., Moore., Brunette., Kozarsky. (2012). Travel and tropical medicine practice among infectious disease practitioners. J Travel Med, 19(2),92-5.

Steffen, at.al. (2004). Epidemiology of Travelers Diarrhea Details pf a Global survey. J TravelMed 11: $231-237$.

Sthepanie, Y. (2015). Strategi Pengembangan Fasilitas Wisata Pantai Sawarna Di Kabupaten Lebak Banten. Universitas Pendidikan Indonesia, repository.upi.edu: perpustakaan.upi.edu. 
Sulistiyorini., Darwis., \& Gutama. (2015). Partisipasi Masyarakat Dalam Pengelolaan Sampah Di Lingkungan Margaluyu Kelurahan Cicurug. Social Work Journal. 5 (1). http://jurnal.unpad.ac.id/share/article/view/13120/5984.

Travel And Tourism Direct Contribution To GDP, US\$ (Billions). https://tcdata360. worldbank.org/indicators/tot.direct.gdp.

Von Sonnenburg, F., Tornieport N., Waiyaki P., Lowe B., Peruski LF., \& Jr. Dupont HL.(2000). Risk and aeriology of diarrhoea at various touris destinations. Lancet 356: 133-134.

Yuliastuti., M Y., \& Jember, I. M. (2013). Partisipasi Masyarakat Dalam Pengelolaan. Sampah Di

Kabupaten Badung. E-Jurnal Ekonomi dan Bisnis Universitas Udayana. 2 (6).374-393 